\title{
REVIEW OF TEMPERATURE MEASUREMENT AND WIRELESS TRANSMISSION OF DATA USING IOT
}

\author{
Milind Shinde, Manohar Dhumal, Nikita Lole, Archana Gharge \\ Dept. of EE \\ ViMEET Khalapur Maharashtra \\ Sarthak Joshi \\ Prof at Dept. of EE \\ ViMEET Khalapur Maharashtra
}

\begin{abstract}
The resolution to make an advancement in the communication domain between instruments and equipment's at the industrial levels is being done with great place which may include wired/ wireless medium for transferring data by using these knowledge we are destined to make a discrete temperature monitoring system of a process. For this various methodologies are being reviewed out of which it was found that wireless medium is the most convenient method.
\end{abstract}

Keywords - Communication, Wired, Wireless, Instruments, Temperature Monitoring.

\section{INTRODUCTION}

Many Industries are now becoming more modern. This modernization is the result of the development of the new instruments, equipment's and the communication technologies. Development in instruments bring out more close monitoring the actual value similarly the development in the equipment leads to the production of greater quality of Product while with the help of communication which is the most important domain through which Information Exchange could take place had a greater evolution having switched from wired to wireless at current scenario.

In this review paper we are going to review the technologies concerning the past and the present ad also reviewing technologies with their present competitors

\section{REVIEW OF TEMPERATURE MEASURINGINSTRUMENTS}

It has been seen that temperature monitoring of a system is mandatory according to the manufacturing of a product was being concerned there are various processes in which measurement of temperature is of utmost importance. A small fluctuation in temperature can make the product quality from better to worse.

Recently there are large number of developed instruments in the current scenario but out of that only one instrument which is feasible, economical, efficient in monitoring the Temperature of a Process. This instruments are a deciding factor for safe and secure operation. Instruments such as RTD, Thermistors, Thermo Couple have a huge demand in the market but only one out of those three can be chosen a detailed comparison [1] of those three is shown in the table below

Table 1. Comparison Between various instruments

\begin{tabular}{|c|c|c|c|}
\hline Sensor Type & Thermistor & RTD & Thermocouple \\
\hline $\begin{array}{l}\text { Temperature } \\
\text { Range(typical) }\end{array}$ & $\begin{array}{l}-100 \text { to } \\
325^{\circ} \mathrm{C}\end{array}$ & -200 to $650^{\circ} \mathrm{C}$ & 200 to $1750^{\circ} \mathrm{C}$ \\
\hline Accuracy & $\begin{array}{l}0,05 \text { to } \\
1.5^{\circ} \mathrm{C}\end{array}$ & 0.1 to $1^{\circ} \mathrm{C}$ & 0.5 to $5^{\circ} \mathrm{C}$ \\
\hline $\begin{array}{l}\text { Long-Term } \\
\text { Stability } \\
\text { @100C }\end{array}$ & $0.2^{\circ} \mathrm{C} /$ year & $0.05^{\circ} \mathrm{C}$ & Variable \\
\hline Linearity & Exponential & Fairly linear & Non linear \\
\hline Power required & $\begin{array}{l}\text { Constant } \\
\text { voltage or } \\
\text { current } \\
\end{array}$ & $\begin{array}{l}\text { Constant } \\
\text { voltage or } \\
\text { current } \\
\end{array}$ & Self-powered \\
\hline Response time & $\begin{array}{c}\text { Fast } 0.1 \text { to } 10 \\
\text { sec }\end{array}$ & $\begin{array}{l}\text { Generally } \\
\text { slow } 1 \text { to } 50 \\
\text { sec }\end{array}$ & Fast 0.10 to $10 \mathrm{sec}$ \\
\hline $\begin{array}{l}\text { Susceptibility to } \\
\text { Electrical noise }\end{array}$ & $\begin{array}{c}\text { Rarely } \\
\text { susceptible } \\
\text { High } \\
\text { resistance only }\end{array}$ & $\begin{array}{c}\text { Rarely } \\
\text { susceptible }\end{array}$ & $\begin{array}{l}\text { Susceptible/ Cold } \\
\text { junction } \\
\text { Compensation }\end{array}$ \\
\hline Cost & $\begin{array}{l}\text { Low to } \\
\text { Moderate }\end{array}$ & High & Low \\
\hline
\end{tabular}

As seen from the table above the parameters in which RTD exceeds the other two is in terms of Accuracy, Susceptibility to electrical noise, Cost and Temperature Range.

For our project we are going to choose RTD for monitoring the Temperature. But due to some technical feasibility we are going to replicate the operation done by RTD by a Potentiometer. The operation of RTD as well as the POT is similar introducing the resistance concurrently to increase in temperature but in RTD the change in temperature will be noted according to the rotation of Knob on the RTD which will introduce resistance

\section{INSTRUMETATION AMPLIFIER CIRCUIT}

The controllers can only take input analog values. Since the values obtained directly from the RTD do not depict temperature values. so in order to measure the change in 


\section{International Journal of Engineering Applied Sciences and Technology, 2020 \\ Vol. 5, Issue 2, ISSN No. 2455-2143, Pages 592-594 \\ Published Online June 2020 in IJEAST (http://www.ijeast.com)}

temperature the output of RTD is given to the wheatstone bridge which gives output in terms of current or voltage. This signal resulted from the wheatstone bridge is of very small amplitude so the signal has to be amplified using amplifier circuits. One such amplifier circuit eing used in industries to amplify the small signals is the instrumentation amplifier. This instrumentation amplifier [2] usually consist of the three OpAmps out of which the two Op-Amps are of voltage follower type and one used as a differential amplifier type. The reason why voltage follower are used is for impedance matching, by matching the input impedance of the Opamps with the Ouput impedance of the circuit. The differential amplifier amplifies the difference of signals obtained from two voltage follower circuit.

\section{REVIEW OF CONTROLLERS}

The value which is amplified does implies the temperature change. So in order to depict the temperature changes the current/voltage values incoming from the Instrumentation amplifier has to be converted into equivalent temperature change for that we need a processing house where the conversion can take place by using arithmetic operations.

In market at present there are currently various processing units available from small controllers to large processors. In this project used of efficient controllers is demanded and good technical feasibility. According to the industries which need highly efficient processing unit for there control action and also the production process should fit in there industry standard.

There are various boards available in the market out of which the two of the boards which are mostly used for building prototype they are Arduino/Node MCU and Raspberry PI. A detailed comparison has been shown in the following table.

Table 2. Comparison of Controllers

\begin{tabular}{|l|l|}
\hline \multicolumn{1}{|c|}{ Raspberry pi3 } & \multicolumn{1}{c|}{ Node MCU } \\
\hline $\begin{array}{l}\text { Stronger and quicker processor, } \\
\text { multitasking available. }\end{array}$ & $\begin{array}{l}\text { Easier to connect to Analog } \\
\text { sensors, motors and other } \\
\text { electronic components }\end{array}$ \\
\hline $\begin{array}{l}\text { Built in Ethernet port, Wi-Fi } \\
\text { Bluetooth capability }\end{array}$ & $\begin{array}{l}\text { Variety of shield that can add } \\
\text { functionality }\end{array}$ \\
\hline OS can be switched easily & $\begin{array}{l}\text { Long Set-up not needed, just } \\
\text { plugged in and the code will run. }\end{array}$ \\
\hline $\begin{array}{l}\text { Audio output, camera port,USB } \\
\text { ports, HDMI output all included. }\end{array}$ & $\begin{array}{l}\text { Price is Cheaper and will not need } \\
\text { much cables }\end{array}$ \\
\hline $\begin{array}{l}\text { Great to start learning to code } \\
\text { with its helpful learning } \\
\text { programs already installed. }\end{array}$ & $\begin{array}{l}\text { Great for projects that need to } \\
\text { quickly get data from sensors and } \\
\text { do one activity from that data. }\end{array}$ \\
\hline $\begin{array}{l}\text { Great for projects that need } \\
\text { to connect online and have } \\
\text { multiple activities going on at } \\
\text { the same time. }\end{array}$ & $\begin{array}{l}\text { Can run one code at time so can't } \\
\text { multitask activities, slower speed. }\end{array}$ \\
\hline $\begin{array}{l}\text { Long set up and will need extra } \\
\text { components when first starting } .\end{array}$ & $\begin{array}{l}\text { No internet connectivity right out } \\
\text { the box }\end{array}$ \\
\hline $\begin{array}{l}\text { Might need to install programs } \\
\text { to get simple actions going }\end{array}$ & $\begin{array}{l}\text { Bigger learning curve since it's } \\
\text { C/C++ and will need to get } \\
\text { outside sources to learn. }\end{array}$ \\
\hline Can be more expensive & Can be cheap \\
\hline
\end{tabular}

From table as seen above the Raspberry $\mathrm{Pi}$ has more processing power and it is more efficient in processing information but as far as the budget has been concerned we are going to use Node MCU. It can also execute instructions but not all the time it can provide the output at exact time, It also has some delay associated with it's instructions processing.

\section{REVIEW OF COMMUNICATION TECHNOLOGIES}

After the voltage values from signal conditioning circuit is converted into equivalent Temperature values, the task now is to transfer the data from sender to receiver. Since Node MCU can also be used for processing the information and also transferring the information so at the sending station where the temperature of process is measured and also the receiving end station where the actual controller is present which controls the process temperature Node MCU is used.

At the receiving end station the actual controller which possess controlling action the receiving end Node MCU sends data to the controller, here the main controller could be a PLC or any other standard industrial controller. The communication will done either through RS232 or RS485 Communication Protocol.

Now the communication between the sender and receiver will be the main factor which will define the process efficiency that how efficiently the temperature is measured, also it will also define the time at which the controlling action would take place. At present communication is most important domain in which there are various mediums of transferring data has been developed. Two mediums which are utilised up till today are wired and wireless mediums. Since due to development of new wireless technologies it is having a big advantage over wired which can be seen in the comparison[3] done in the table shown below .

Table 3: Comparison of Controllers

\begin{tabular}{|l|l|l|}
\hline Parameters & Wired & Wireless \\
\hline Communication & Copper, fiber etc. & Air \\
\hline standard & IEEE 802.3 & 802.11 family \\
\hline Mobility and Roaming & Limited & Higher \\
\hline \multicolumn{1}{|c|}{ Security } & High & $\begin{array}{l}\text { Lower than wired. } \\
\text { Also easy to hack }\end{array}$ \\
\hline Speed /Bandwidth & $\begin{array}{l}\text { High speed upto 1 } \\
\text { Gbps }\end{array}$ & $\begin{array}{l}\text { Lower speed than } \\
\text { wired network. }\end{array}$ \\
\hline Access to network & $\begin{array}{l}\text { Physical Accesss } \\
\text { required }\end{array}$ & proximity required \\
\hline Delay & Low & High \\
\hline Reliability & High & Lower than wired \\
\hline Flexibility to change & $\begin{array}{l}\text { Less flexible to } \\
\text { changes }\end{array}$ & $\begin{array}{l}\text { More flexible } \\
\text { configuration }\end{array}$ \\
\hline $\begin{array}{l}\text { Interference and } \\
\text { Fluctuations } \\
\text { vulnerability }\end{array}$ & Very Less & High \\
\hline Installation activity & $\begin{array}{l}\text { Cumbersome and } \\
\text { manpower intensive }\end{array}$ & $\begin{array}{l}\text { Less labor intensive } \\
\text { and easy }\end{array}$ \\
\hline Installation Time & $\begin{array}{l}\text { Takes longer time to } \\
\text { perfom installation }\end{array}$ & $\begin{array}{l}\text { Very less deployment } \\
\text { time }\end{array}$ \\
\hline Installation Cost & High & Low \\
\hline Mainatenance cost & High & Low \\
\hline Related equipment & Router, switch, hub & $\begin{array}{l}\text { Wireless router, } \\
\text { Access point }\end{array}$ \\
\hline
\end{tabular}


International Journal of Engineering Applied Sciences and Technology, 2020

Vol. 5, Issue 2, ISSN No. 2455-2143, Pages 592-594

Published Online June 2020 in IJEAST (http://www.ijeast.com)

\begin{tabular}{|l|l|l|}
\hline Benefits & Greater speed & No massless of cable \\
& $\begin{array}{l}\text { Higher noise } \\
\text { immunity } \\
\text { Highly reliable }\end{array}$ & $\begin{array}{l}\text { Best for mobile } \\
\text { devices }\end{array}$ \\
& Greater security & $\begin{array}{l}\text { Gasy installation and } \\
\text { management. }\end{array}$ \\
\hline
\end{tabular}

From the table it can be seen that the wireless medium has the help from signal conditioning circuit which will amplify the small voltage signal to a large signal of suitable which can be sensed by the controller by adjusting the gain of the amplifier circuit. The wheatstone bridge and the amplifier circuit comes under on technical device which is called as Signal Conditioning circuit. Here the controller used can an Arduino Uno Board or a Node MCU, Node MCU will be used because it has inbuilt Wifi module. The voltage signal which is available from the Signal Conditioning device at the Analog terminals of Node MCU will be converted into temperature values equivalent to the voltage value. The NODe MCU at the sender and receiver are connected to the internet and will exchange the information. The receiving side Node MCU will send the data directly to the PLC.

\section{CONCLUSION}

As far as the review of methodologies has been done it was decided that the RTD is used for measuring temperature because it is more feasible and economical, whereas the development of the instrumentation amplifier is been used with help of which the signal is amplified which will be sensed by the Node MCU(sender) while using it to transmit the data wirelessly, while Node MCU(receiver) has been used at the receiving end which will receive the data from the sender either store the data or it will send the data to the cloud finally the data will reach PLC which will closely monitor the operation.

\section{METHODOLOGY}

Following block diagram shows the finalized methodology

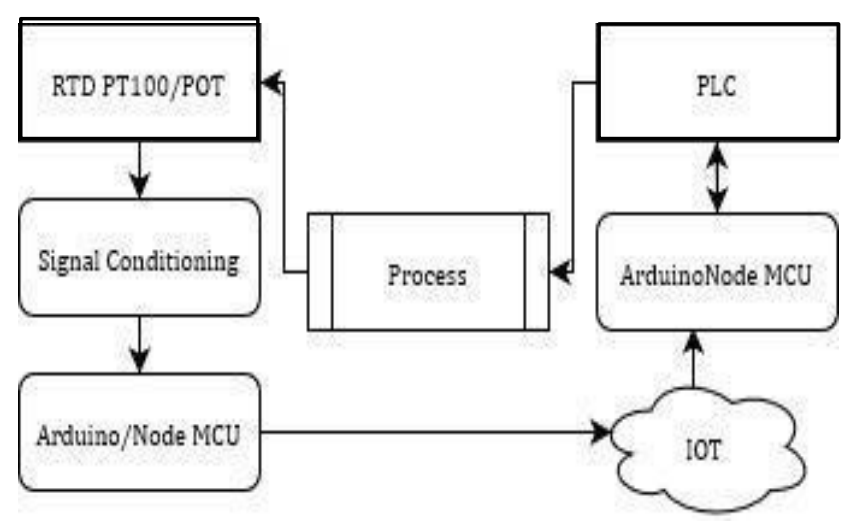

Fig. 1. Process flow diagram

RTD PT100 if available then can be used to measure the temperature in terms of resistance, If not present than the Potentiometer will operate as similar to the RTD which will include change in resistance. This change in resistance is measured in the wheatstone bridge which gives the output in terms of voltage since the voltage is so small we have to take the upper hand. Wireless medium due to its flexibility and economical feasibility has been the best option to share information from sender to receiver.

\section{REFERENCE}

[1] https://www.analogictips.com/temperature-sensorsthermocouple-vs-rtd-vs-thermistor-vs-semiconductoric/

[2] https://www.youtube.com/watch?v=d7aZKfW3tLk

[3] https://www.arrow.com/en/research-andevents/articles/comparing-arduino-uno-and-raspberry-pi-3

[4] https://ipwithease.com/wired-network-vs-wirelessnetwork/University Science, 1989 